\title{
JAETUSTA LANNOITUKSESTA KEINO TYPEN VESISTÖKUORMITUKSEN HILLITSEMISEKSI?
}

\author{
Kari Hyytiäinen ${ }^{1)}$, Jarkko K. Niemi ${ }^{1)}$, Kauko Koikkalainen ${ }^{1)}$, Taru Palosuo ${ }^{1)}$ ja Tapio Salo ${ }^{2)}$ \\ ${ }^{1)}$ MTT, Latokartanonkaari 9, 00790 Helsinki \\ ${ }^{2)}$ MTT, 31600 Jokioinen
}

\section{TIIVISTELMÄ}

Vesiensuojelun tarpeet kiristävät vaatimuksia maatalouden vesistökuormituksen vähentämiseksi ja lisäävät kysyntää uusille vesiensuojelua edistäville keinoille. Jaettu lannoitus on varteenotettava ja Suomessa vähän sovellettu keino vesistökuormituksen hillitsemiseksi. Tässä tutkimuksessa tarkasteltiin jaetun lannoituksen taloudellisia vaikutuksia ja vesistökuormitusta viljelijän päätöksentekomallin avulla. Malli kalibroitiin mallasohralle ja eteläsuomalaiselle savipellolle. Mallin avulla voidaan laskea optimaalisia typpilannoitusohjelmia erilaisilla viljan hinnoilla, kustannustasoilla ja ympäristöpainotuksilla. Malli ottaa myös huomioon vaihtelevien sääolojen vaikutuksen satoon, viljelijän saamiin tuloihin, typen huuhtoutumiseen ja epävarmuuden vaikutuksen rationaalisesti toimivan viljelijän päätöksiin. Kylvön yhteydessä tehtävän sijoituslannoituksen lisäksi viljelijä voi päättää lisälannoituksesta kasvukauden aikana kolmena ajanhetkenä ottaen huomioon kasvuston sekä maaperän typpivarasto suuruuden.

Tulostemme mukaan viljelijän ei kannatta siirtyä jaettuun typpilannoitukseen, kun päätöksentekoa tarkastellaan pitkän aikavälin keskiarvoihin asetetuilla viljan ja tuotantopanosten hinnoilla. Peltolohkon tuottoa maksimoivan viljelijän kannattaa laittaa sijoituslannoituksessa riittävä määrä typpeä koko kasvukauden tarpeisiin. Toisaalta, jos viljelijä ottaa typen huuhtoutumisen ympäristövaikutukset huomioon, vaikka hyvinkin pienellä painolla, kannattaa lannoitus jakaa useampaan osaan. Jaetulla lannoituksella saadaan suuremmat keskiarvoiset sadot vuosittain pienemmällä typen vesistökuormituksella, mutta hiukan suuremmin kustannuksin.

Jaettu lannoitus on ollut puutarhaviljelyssä käytössä jo vuosikymmeniä. Peltoviljelyssä sitä on sovellettu lähinnä intensiivisen peltoviljelyn maissa. Viime aikoina kohonneet viljan ja tuotantopanosten hinnat sekä kansalaisten huoli vesistöjemme tilasta voivat kuitenkin luoda kysyntää menetelmän sovelluksille myös Suomessa. Menetelmällä on potentiaalia etenkin huuhtoutumisherkimmillä vesistöihin rajoittuvilla pelloilla, jotka halutaan kuitenkin pitää viljelyssä hyvätuottoisuutensa tai muiden syiden takia. Kasvukauden aikaisen lannoituksen suotuisat ympäristövaikutukset on kuitenkin syytä varmentaa koejärjestelyin, ennen kuin Suomessa vähän sovellettu menetelmä otetaan laajamittaisempaan käyttöön. Jaettu lannoitus on luontevaa kytkeä täsmäviljelyyn, jossa lannoituksen määrää vaihdellaan pellon eri osien tuotantopotentiaalin ja huuhtoutumisherkkyyden perusteella.

Asiasanat: lannoitus, optimointi, ohra, typpi, huuhtouma, ympäristöpolitiikka 


\section{JOHDANTO}

Jaettu lannoitus nousee aika ajoin esille viljelijöiden, tutkijoiden ja maataloushallinnon keskusteluissa. Jaettua lannoitusta on sovellettu puutarhaviljelyssä jo vuosikymmeniä ja se on yleistynyt myös peltoviljelyssä intensiivisimmän viljelyn alueilla (esim. Alankomaissa). Suomalaisessa peltoviljelyssä jaettua lannoitusta on kuitenkin pidetty työläänä ja siten kalliina saavutettavissa oleviin hyötyihin nähden. Menetelmän hyötyjä perinteiseen kylvön yhteydessä toteutettavaan kertalannoitukseen verrattuna ovat mahdollisuudet mitoittaa lannoitteen määrä paremmin kasvien kasvukauden aikaisen käyttökyvyn mukaan ja pienempi vesistökuormitus.

Kansalaisten lisääntyvä ympäristötietoisuus ja jatkuvasti kiristyvät vaatimukset maatalouden ympäristökuormituksen vähentämiseksi ovat lisänneet paineita hakea uusia keinoja, ja tarkastella uudestaan vanhoja keinoja, maatalouden vesistökuormituksen vähentämiseksi. Tässä tutkimuksessa tarkasteltiin mahdollisuuksia typen jaettuun lannoitukseen suomalaisessa peltoviljelyssä. Tarkastelutasona on yksittäinen peltolohko tai peltolohkon osa, joka on ominaisuuksiltaan homogeeninen. Tutkimuksessa kehitettiin rationaalisesti toimivan viljelijän päätöksentekoa kuvaava optimointimallikonsepti (Hyytiäinen ym. 2011), jolla voidaan ratkaista typpilannoitteen optimaalinen käyttömäärä neljänä eri ajanhetkenä kasvukauden aikana. Konseptimalli on stokastinen ja se ottaa huomioon myös vuotuisen säävaihteluiden aiheuttaman epävarmuuden kasvuston kehityksestä ja typen huuhtoutumisesta.

\section{AINEISTO JA MENETELMÄT}

Optimointimallin rakenne on havainnollistettu kuvassa 1. Aluksi valitaan viljeltävä kasvi ja peltolohko, jolle laskelmat tehdään. Seuraavaksi kootaan päivän tarkkuudella kerättyä tietoa toteutuneista sääoloista (sateisuus, lämpötila jne.) menneiltä vuosilta ja liitetään se syöttötiedoksi kasvuston kehitystä ja maaperän prosesseja kuvaaviin simulaatiomalleihin (COUP ja WOFOST). Kasvu- ja maaperämalleilla kuvataan sadon ja kasvuston kehitys sekä näihin liittyvät maaperäprosessit (ml. huuhtoutuminen) sääaineiston kattavalle ajanjaksolle. Lisäksi kerätään tietoa tuotantopanosten hinnoista ja viljan hinnoista viljelyn katetuoton laskemista varten. Käytimme laskelmissamme viime vuosien keskiarvoisia hintoja ja kustannustasoa. Rehu- ja mallasohran hintoina käytettiin 81,90 ja $133,70 € /$ tonni ja typpilannoitteen hinta oli $0,98 € / \mathrm{kg}$.

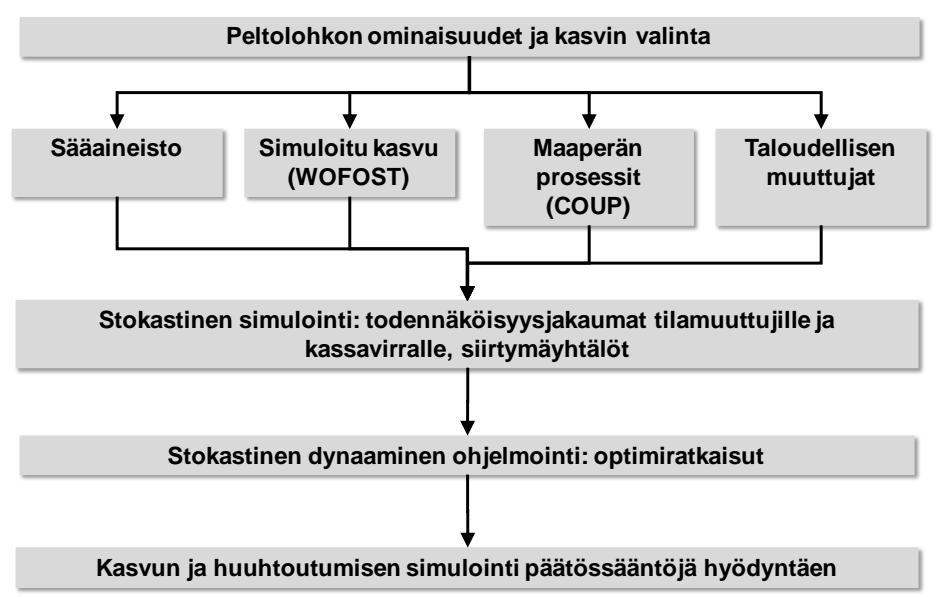

Kuva 1. Optimointimallin rakenne ja komponentit

Mallia varten kerätty tieto yhdistetään stokastisessa simulointimallissa, joka simuloi sadolle ja viljelijän vuotuiselle kassavirralle erilaisia sääolojen vaihtelusta aiheutuvia toteutumia. Simulointimallin avulla voidaan myös luoda vaihtoehtoisia kehitysuria typen liikkeistä maaperästä kasvustoon, satoon ja vesistöihin pintavalunnan ja salaojien kautta. Monte Carlo simulointia käyttäen mallilla tuotetaan siirtymätodennäköisyydet typen liikkeille maaperän, kasvuston ja vesistön välillä. Lannoituksen päätössäännöt lasketaan rekursiivisesti stokastista dynaamista ohjelmointia (Bellman 1957) käyttäen. Optimointimallissa tavoitteena on maksimoida peltolohkon tuottoarvo kymmenen vuoden tarkastelujaksolla ja lannoitusmääriä päätösmuuttujana käyttäen. Optimoituja 
lannoituspäätössääntöjä ja optimointimallin rajoitteita ja tunnuslukuja tarkastelemalla voidaan selvittää optimoinnin vaikutus peltolohkon tuottoarvoon, typestä aiheutuvaan vesistökuormitukseen ja politiikkatoimien vaikuttavuuteen.

Tutkimuksssa käytetty optimointimalli kalibroitiin mallasohralle ja eteläsuomalaiselle savipellolle. Kasvumallina käytettiin WOFOST-mallia (Boogard et al. 1998) ja maaperän prosessien kuvauksessa COUP-mallia (Jansson ja Karlberg 2009). Mallin avulla voidaan laskea optimaalisia typpilannoitusohjelmia erilaisilla viljan hinnoilla, tuotantopanosten kustannustasoilla ja ympäristöpainotuksilla. Malli ottaa huomioon vaihtelevien sääolojen vaikutuksen satoon, viljelijän saamiin tuloihin, typen huuhtoutumiseen ja epävarmuuden vaikutuksen optimaalisiin päätöksiin. Kasvukausi jaettiin neljään jaksoon, joina viljelijä voi tehdä päätöksiä lisälannoituksesta kasvuston sekä maaperän sen hetkisen typpivaraston perusteella. Ensimmäinen lannoitus tehdään normaalisti sijoituslannoituksena, toinen ja kolmas lannoitus pintalannoituksena sekä viimeinen lannoitus lehtilannoituksena. Simulointi- ja optimointimallien sisältö ja käyttö optimoinnissa on dokumentoitu yksityiskohtaisemmin julkaisussa Hyytiäinen et al. (2011)

\section{TULOKSET}

Ensin havainnollistamme simulointimallin toimintaa eksogeenisesti, ilman optimointia määrätyillä kylvön yhteydessä annetuilla lannoitemäärillä. Kuvassa 2 on jakaumat viljelijän ohranviljelystä saamalle taloudelliselle ylijäämälle 0 - $200 \mathrm{~kg} / \mathrm{ha}$ lannoitemäärillä. Laatikoiden keskellä oleva viiva kuvaa katteen odotusarvoa, laatikon reunat $50 \%$ luottamisväliä, ulommat janat $80 \%$ luottamusväliä ja näiden ulkopuolelle jäävät pisteet yksittäisiä poikkeuksellisia havaintoja. Vaihtelevat sääolot vaikuttavat vuotuiseen sadon määrään ja laatuun sekä peltolohkon tuottoarvoon. Tuoton odotusarvo on suurimmillaan, kun lannoitemäärä on $90 \mathrm{~kg}$ typpeä hehtaarille. Sitä suuremmilla lannoitusmäärillä vuotuisen katteen odotusarvo pienenee ja hajonta kasvaa. Tämä tulos soveltuu päätössäännöksi viljelijälle, joka ei harkitse kasvukauden aikaista lannoitusta eikä pyri mitoittamaan lannoituksen määrää kasvukauden satonäkymien suhteen (lannoittaa joka vuosi samalla tavalla).

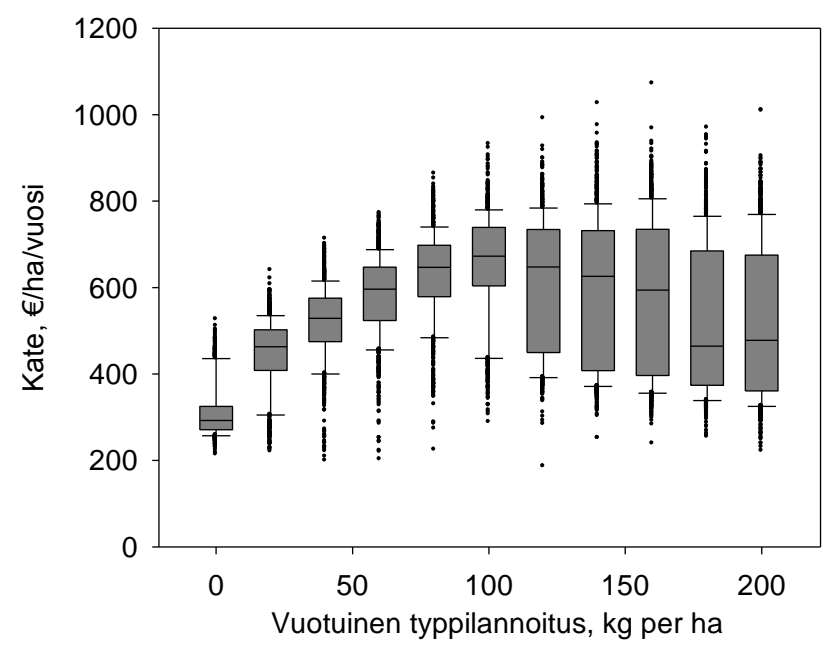

Kuva 2. Sijoituslannoituksen määrän vaikutus viljelijän saamaan katteeseen

Toiseksi tarkastelemme tilannetta, jossa viljelijä optimoi lannoitepäätökset sijoituslannoituksen lisäksi kolmena muuna ajankohtana kasvukaudella. Tulosten mukaan viljelijän kannattaa edelleen mitoittaa typpilannoitus kylvön yhteydessä koko kasvukautta silmälläpitäen ja tarvittaessa täydentää lannoitusta myöhemmin. Kuva 3 esittää päätössäännöt kasvukauden aikana tapahtuvalle kolmannelle lannoitukselle. Optimaalinen lannoitusmäärä vaihtelee välillä $0-150 \mathrm{~kg} / \mathrm{ha}$ kasvuston ja maaperässä kasvien käytettävissä olevan typen perusteella. Lannoitemäärä on sitä pienempi mitä enemmän maaperässä on jäljellä typpeä sijoituslannoituksen jäljiltä. Typpilannoitteen käyttömäärä on sitä pienempi mitä pienempi on kasvustoon sitoutuneen typen määrä. Vähäinen typen määrä kasvustossa on yhteydessä pieneen tuotospotentiaaliin jäljellä olevalla kasvukaudella. Tyypillisenä vuonna, jolloin kasvusto on kehittynyt normaalisti ja huuhtoutuminen on ollut keskivertovuoden tasoa, 
sijoituslannoituksen yhteydessä annettu typpi kuitenkin riittää koko kasvukaudelle eikä tarvetta kasvukauden aikaiselle lannoittamiselle ole.

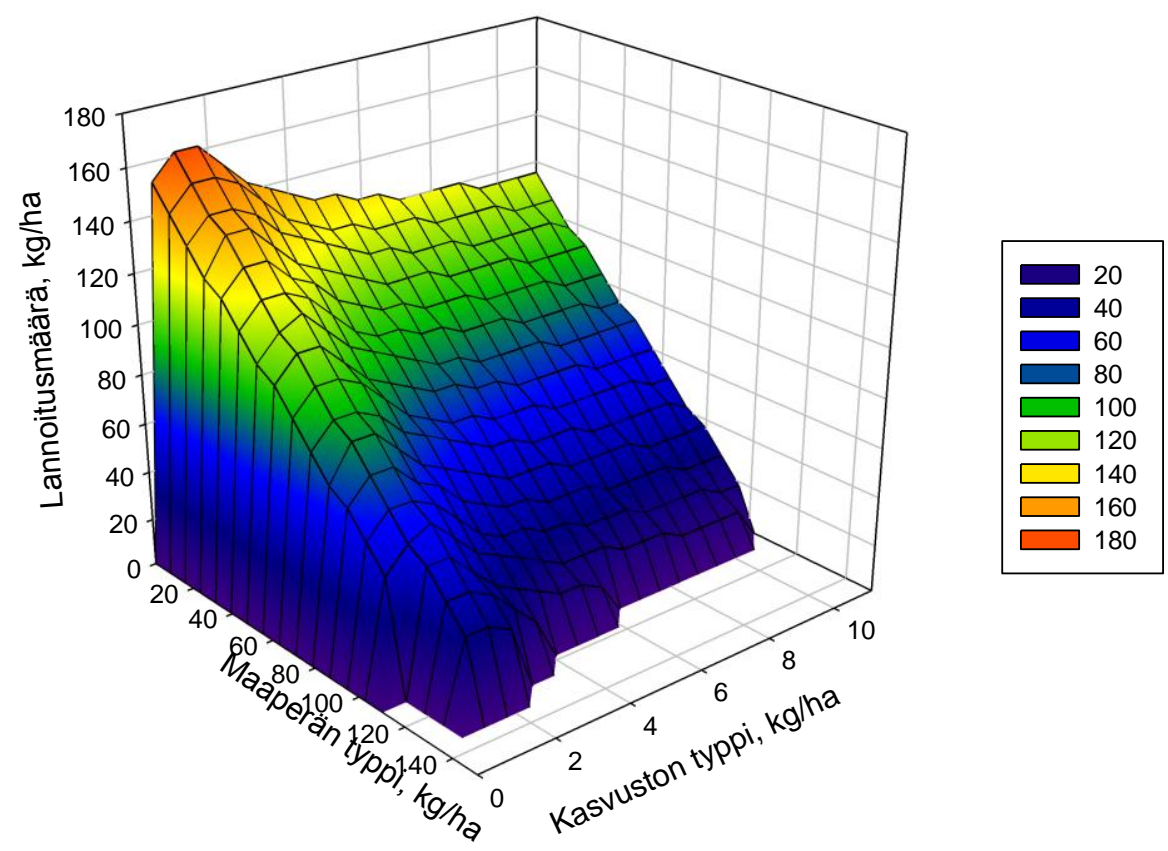

Kuva 3. Esimerkki optimoinnin tuloksista: päätössäännöt lannoitemäärälle kolmannella lannoituskerralla.

Lopuksi tarkastelemme tilannetta, jossa viljelijän peltolohkolle saamassa tuotossa otetaan huomioon myös typen vesistökuormituksen aiheuttamia haittoja. Tämä tehdään asettamalla typpikuormitukselle maksu, joka kuvaa peltoviljelyn negatiivisia ulkoisvaikutuksia ja vesistökuormituksen yhteiskunnallisia kustannuksia. Jo pienillä ympäristöpäästöjä painottavalla maksulla viljelijän kannattaa jakaa lannoitus useammalle lannoituskerralle tai siirtyä kokonaisuudessaan kasvukauden aikaiseen lannoitukseen.

Typen kuormitusvero muuttaa optimaalisen lannoituksen päätössääntöjä. Lannoitus kuitenkin mitoitetaan edelleen siten, että useimpina vuosina lannoituskertoja on kasvukauden aikana vain 1-2. Tulos johtunee jokaiseen lisälannoituskertaan liittyvistä aloituskustannuksista. Kuva 4 esittää jakaumat typen vesistökuormitukselle optimaalisilla lannoitepäätöksillä ja erilaisille typpikuormitusmaksun tasoilla. Jaetun lannoituksen käyttöönotto pienentää odotettua vesistökuormitusta ja vähentää sellaisten vuosien todennäköisyyttä, jolloin kuormitus on hyvin korkea (yli $30 \mathrm{~kg} / \mathrm{ha} / \mathrm{vuosi}$ ). Jaetun lannoitukset hyödyt korostuvat vasta korkeammilla maksutasoilla, jolloin vähennetään myös lannoitusmääriä.

Mahdollisuus jaettuun ja kasvukauden aikaiseen lannoitukseen lisää viljelijän peltolohkolle saamaa tuottoa sekä nostaa hehtaarisatoja ja yllättäen myös lannoitemääriä. Sen sijaan typen vesistökuormitus pienenee kertalannoitukseen verrattuna. Sadon määrään suhteutettuna typen vesistökuormitus kuitenkin voi jaetun lannoituksen ansiosta pienentyä merkittävästikin. 


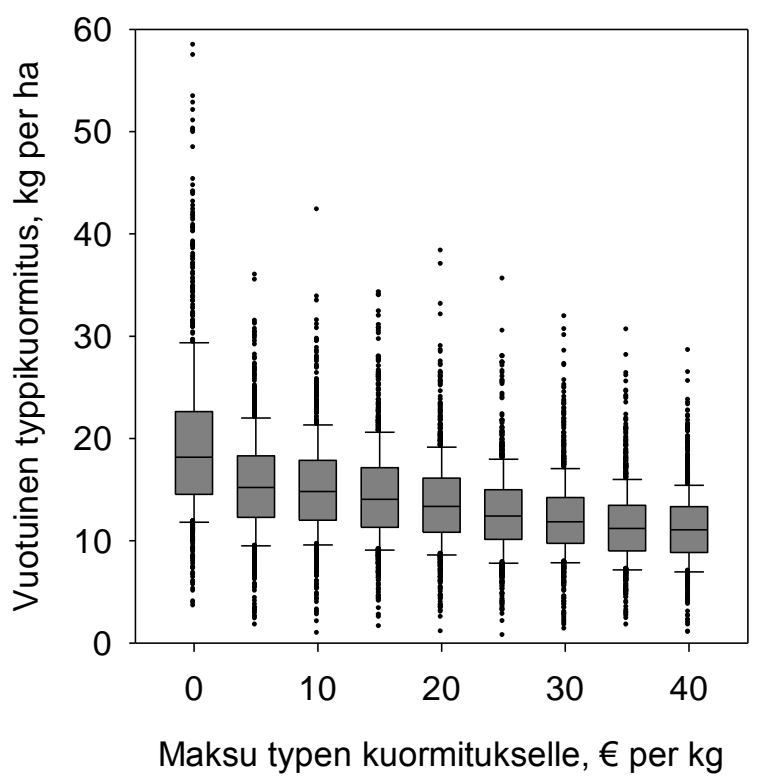

Kuva 4. Vuotuinen typen kuormitus optimaalisilla lannoituspäätöksillä ja erilaisilla typen kuormitusmaksun tasoilla

\section{JOHTOPÄÄTÖKSET}

Tulokset viittaavat siihen, että taloudellista voittoa maksimoivan viljelijän ei kannatta siirtyä jaettuun lannoitukseen pitkän aikavälin keskiarvoisilla viljan hinnoilla ja tuotantopanosten kustannuksilla laskettuna. Typpilannoitus kannattaa tehdä perinteiseen tapaan kylvön yhteydessä sijoituslannoituksena ja mitoittaa määrä koko kasvukautta silmälläpitäen. Lannoitusta kannattaa tarvittaessa täydentää kasvukauden aikana.

Jaettu lannoitus on lupaava keino yhdistää ympäristötavoitteita peltoviljelyyn kohtuukustannuksin. Menetelmällä on mahdollisuuksia esim. ympäristötuen instrumenttina etenkin kaikkein huuhtoutumisherkimmillä vesistöihin rajoittuvilla pelloilla, jotka halutaan pitää viljelyssä hyvätuottoisuutensa tai muun syyn takia. Kasvukauden aikaisen lannoituksen suotuisat ympäristövaikutukset on kuitenkin syytä varmentaa koejärjestelyin, ennen kuin Suomessa aiemmin vähän sovellettu menetelmä otetaan laajamittaiseen käyttöön.

Viime aikoina kohonneet viljan ja tuotantopanosten hinnat sekä kansalaisten huoli vesistöjemme tilasta voivat luoda kannustimen jaetun lannoituksen laajamittaisemmalle soveltamiselle myös Suomessa. Jaettu lannoitus on luontevinta kytkeä täsmäviljelyyn, jossa lannoituksen määrää vaihdellaan pellon eri osien tuotantopotentiaalin ja huuhtoutumisherkkyyden perusteella. Kaukokartoitus ja GPS-tekniikat täsmäviljelyssä kehittyvät, kun niitä otetaan käyttöön intensiivisemmän peltoviljelyn maissa. Yleistyttyään myös teknologian kustannukset vähenevät. Kenties jaettu lannoitus ja täsmäviljely ovat arkipäivää suomalaisessa maanviljelyssä muutaman vuosikymmenen kuluessa.

\section{KIRJALLISUUS}

Bellman, R. 1957. Dynamic Programming. New Jersey: Princeton University Press. 339 p.

Boogaard, H.L., van Diepen, C.A., Rötter, R.P., Cabrera, J.M.C.A., Van Laar, H.H. 1998. User's guide for the WOFOST 7.1 crop growth simulation model and WOFOST Control Center 1.5. Technical Document 52. DLO Winand Staring Centre, Wageningen, 1998.

Hyytiäinen, K., Niemi, J.K., Koikkalainen, K., Palosuo, T., Salo, T. 2011. Adaptive Optimization of Crop Production and Nitrogen Leaching Abatement under Yield Uncertainty. Agricultural Systems 104: 634-644.

Jansson, P.-E. and Karlberg, L. 2009. Coupled heat and mass transfer model for soil-plant-atmosphere systems. (Update 7.10.2009). Available at: http://www.lwr.kth.se/vara\%20datorprogram/CoupModel/index.htm 